\title{
BUSINESS OWNER AND MANAGER'S ATTITUDES TOWARDS FINANCIAL DECISION-MAKING AND STRATEGIC PLANNING: EVIDENCE FROM CROATIAN SMES
}

\author{
Marina Klačmer Čalopa*
}

Received: 19. 7. 2016

Accepted: 29. 5. 2017

Review

UDC $005.21-022.51 / .55(497.5)$

The main goal of the paper was to explore the attitude of business owners and managers in the small and medium sized companies (SMEs) in Croatia toward financial decision-making and strategic planning. In addition, it is attempted to identify managers' styles and entrepreneurial skills, as well as the level of their financial knowledge. Data was gathered using online questionnaire method and analyzed with standard tools of descriptive statistics. The research sample consisted of 106 respondents from SMEs in Croatia (14\% response rate). Research results reveal that business owners and managers are concerned about financial results but, unfortunately, do not influence the financial decision-making in all of its stages. The study could contribute to a better understanding of attitudes of Croatian SMEs business owners and managers toward financial decision-making and strategic planning.

Key-words: SMEs, Business owners, Managers, Financial decision-making, Strategic planning

\section{INTRODUCTION}

Small and medium sized companies, as a backbone of the Croatian economy, should create a wide range of financial and management knowledge to serve as a competitive advantage in the process of decision-making. The SME sector contributes to economic development, job creation, to reduction of regional development gaps, and to developing innovative capabilities (Vidučić et al., 2013). Business owners' and managers' attitudes in Croatian SMEs companies were explored in the context of their financial decision-making process and strategic planning. The literature and the practice can identify

* Marina Klačmer Čalopa, PhD, Associate Professor, Faculty of Organization and Informatics, University of Zagreb, Pavlinska 2, 42000 Varaždin, Croatia, E-mail: marina.klacmer@foi.hr 
different types of planning important for sustainable business success. Those are financial and strategic planning. The present study has both theoretical and empirical significance. For research purposes, online survey questionnaire was created using Google Documents tool as a measuring instrument for collecting data. In the questionnaire, mostly closed-ended questions were used. Also, the Likert model of the questionnaire has been used, with statements to be rated on a scale from 1 to 5 .

Data were collected from 106 business owners and managers of SMEs in Croatia. Collected data were analyzed using Microsoft Excel and interpreted using standard tools of descriptive statistics. Analysis revealed that business owners and managers are concerned about financial results, but unfortunately they do not have impact on decision-making from the financial perspective in every phase of the decision-making process. The most influential function they have in the process of financial decision-making is the organizational one which is considered one of the major functions of the management process.

The study is organized into three major sections. The first section provides an analytical review of the latest articles about financial decision-making and strategic planning in the small and medium sized companies. The second section turns to the problem of research agendas. A detailed analysis and research results are shown in the measurement development and research results section. Conclusions, limitations and implications for further research are presented in the third section at the end of the paper.

\section{THEORETICAL BACKGROUND - FINANCIAL DECISION- MAKING AND STRATEGIC PLANNING IN SMES}

The analyzed literature (Pasadilla, 2010; Culkin, Smith, 2000) shows that the definition of SMEs is usually based on the number of employees and capital thresholds and that those companies are the largest component of business sector in every global economy. Despite the many problems encountered by SMEs $^{1}$ in Croatia, the share of these companies in the Croatian economy is also significant and recognizable. (GEM Croatia, 2016).

SME sector has the potential to quickly respond to the changes in the context of global environmental change (Shahzad et al., 2010) which is an

\footnotetext{
${ }^{1}$ Small and medium sized businesses that are obliged to pay profit tax, as well as crafts whose owners pay income tax, were included into the SME sector in this study. Differentiation of SMEs in Croatia is made according to the Law on Accounting, "Narodne novine" - Official gazette of the Republic of Croatia, 109/07, 54/13, 121/14
} 
Management, Vol. 22, 2017, 1, pp. 103-116

M. Klačmer Čalopa: Business owner and manager's attitudes towards financial decision ...

important dimension for financial decision-making process and strategic planning. The decision-making process in the SMEs typically involves more compelex strategic behavior than is commonly recognized (Reboud, Mazzarol, 2008), and management is often analysed from the qualitative aspect which emphasizes the use of creativity and intuition (İbicioğlu, Kocabiyik, Dağlar, 2010). Some other conducted studies (Kraus, Reiche, Reschke, 2007; Kono, Barnes, 2010) show that communication skills, teamwork skills and financial knowledge are very important for strategic decision-making but business owners and managers in SMEs still have an insufficient business knowledge for making financial decisions and performing strategic planning. Financial literacy is important for effective decisions in the running of the business. Recent findings (Klapper, Lusardi \& Panos, 2015) suggest that financial literacy exerts a high impact on business performance in the SMEs in the US.

Financial management is more focused on organizing function, on collecting financial data and developing financial statements. Financial leadership should be more focused on planning and leadership of the organization in order to achieve financial sustainability. Possessing knowledge about developing financial plans is also critical because it helps in evaluating current financial position and the potential for future financial performance (Jones, 2002). In the organizational hierarchy, financial leaders are usually executive directors responsible for developing and maintaining a business framework (Barr, Bell, 2011). Finance directors in some organizations have a very wide set of responsibilities. They are strategic business counsellors (CIMA, 2007) or they play some other important role as a part of the management team. Liu (2010), in his research presents strategic financial management theory which refers to financial management theories according to which "financing should be conducted in the most proper way, the collected capital should be utilized and managed in the most effective way and decisions on the reinvestment and distribution of profits should be made most reasonably".

In her paper, Niles (2010) concludes that integrating strategic and financial planning is the best way to ensure budget allocations. The shift from financial management to strategic financial management has a positive impact to the concept of improving SMEs performance (Karadag, 2015). The role of finance in strategic planning and in the decision-making process is crucial. This can be explained with the fact that financial metrics have been applying the same standard for assessing a firm's performance for a long time (Kono, Barnes, 2010). According to Grebe (2005), strategic planning is essential to successful financial performance. Furthermore, Verreynne (2006) points out the link 
Management, Vol. 22, 2017, 1, pp. 103-116

M. Klačmer Čalopa: Business owner and manager's attitudes towards financial decision ...

between strategic decision-making and the performance of SMEs. She identifies different types of strategic decision that exhibit different influences on companies' performance.

Njuguna Chege, Wachira and Mwenda (2015), in their research on SMEs in Kenya, came to the conclusion that autocratic leadership style had the strongest effect on the implementation of strategic plans but that democratic leadership and laissez faire also have a positive effect on implementation of strategic plans. Sage (2015) defined implementation as "the process that turns strategies and plans into actions". Similarly, Kraus, Reiche and Reschke (2007) defined strategic planning "as an attempt to prepare for all eventualities and as a need to build alternative future scenarios and configurations". Reboud and Mazzarol (2008) came to the conclusion that strategy and strategic thinking are less of a problem for the business owner or manager in the SMEs than is their ability to engage in a process of planning.

Strategy implementation, especially in SMEs, remains a major challenge in the business world and a lot of research acknowledges that fact (Njuguna Chege, Wachira and Mwenda, 2015). On a global scale, and in Croatia as well, the effect of different management styles on the implementation of strategic plans has not received enough attention. Van Auken and Yang (2014) conducted research on 46 Chinese SMEs. They found out that owners use financial statements to make decisions according to the frequency of the available financial statements and their ability to interpret the information. İbicioğlu, Kocabiyik and Dağlar (2010) conducted research on 71 SMEs in Turkey and 60 SMEs in European countries and found out that the managers use financial statement data as a tool for decision-making.

\section{MEASUREMENT PROCESS AND RESEARCH RESULTS}

\subsection{Research methodology, data collection and research questions}

The aim of the study was to explore business owners' and manager's attitudes towards financial decision- making process and strategic planning in SMEs in Croatia. As a measuring instrument for collecting data, an online survey questionnaire with 24 questions was used. The revised version of the measuring instrument used for this study was originally developed for the research in the doctoral dissertation (Dmitrović, 2015), referring to the previous research and used with the author's permission. The questionnaire included closed-ended questions and the 5-point Likert scale. The link to the questionnaire was sent to 756 e-mail addresses of small and medium-sized 
Management, Vol. 22, 2017, 1, pp. 103-116

M. Klačmer Čalopa: Business owner and manager's attitudes towards financial decision ...

companies in Croatia collected from the Business Register of the Croatian Chamber of Commerce (CCC). Survey in Croatia was conducted during the year 2015. In total, 106 questionnaires were collected. The response rate is $14 \%$. The sample size was deemed sufficient for this type of research. In addition, the response rate in Croatia is similar and comparable to previously conducted international studies. The collected data were analyzed and interpreted using standard tools of descriptive statistics. The data were summarized by use of means, mode, and median as a form of central tendency and standard deviation as a form of variability to provide a better understanding of the business owners' and managers' responses. The methods of deduction and generalizations were adopted for drawing conclusions. Taking into account the aim of the study and the literature review, three research questions were formulated:

RQ1 Do business owners and managers in SMEs in Croatia have a significant impact on financial decision-making?

The answer to this research question is viewed from the aspect of the four functions of management, i.e. planning, organizing, leading and controlling. Each management process begins with planning which involves strategic orientation or defining business goals and the methods to achieve them. The following function of management is organizing in which the managers select appropriate activities, responsibilities and the company structure. Many authors believe that this is the most critical of all managerial functions (study.com). Leading includes motivating, the choice between different styles and channel of communication with people. Controlling is a function of management that involves analyzing metrics during business activities and taking corrective actions (Carpenter, Bauer, Erdogan, 2012).

RQ2 Do high-level management and their ethical principles have the biggest influence on the process of financial decision-making in SMEs in Croatia?

Professional ethics, defined through the standards of ethical behavior for management, is extremely important in the decision-making process, especially in finance. "Ethical decision-making refers to the process of evaluating and choosing among alternatives in a manner consistent with ethical principles" (blink.ucsd.edu). Business owners' and manager's responsibility is important in terms of harmonizing managerial decisions and actions with ethical values. Therefore, dealing with ethics in the financial services industry should be a part of its core business (Winbladh, 2013). 
Management, Vol. 22, 2017, 1, pp. 103-116

M. Klačmer Čalopa: Business owner and manager's attitudes towards financial decision ...

RQ3 Are there differences in the impact of financial decision process on selected factors like innovation, intellectual capital, speed of decisionmaking and reward for effort in a company?

The adoption of innovative decisions in the area of finance can generate new ideas and changes in the static data such as financial statements. Intellectual capital is looking to consider the organizational knowledge, intelligence and experience in order to achieve comprehensive development and knowledge expansion. More than ever before, those factors have become crucial for making sound business decisions (Jouzani, 2015).

For this reason, financial analysis is very important. Speed of decisionmaking is a key element in financial analysis and it depends on the problem complexity, on the confidence in financial knowledge and on managing finance as well as on the number of alternatives from the financial point of view. In the available literature, the objective financial knowledge, from the aspect of confidence, is referred to as financial literacy (Sprenger, 2016). Some analyzing tools, also known as corporate performance management, could speed up financial processes such as budgeting, forecasting and some others (CIMA, 2007). Finally, participating in the decision-making process enables greater initiative and increased motivation (rewarding) and productivity.

\section{RESEARCH RESULTS}

Results indicate that respondents, in most cases (59\%), were higher-level managers in small and medium sized companies (usually also owners) and 68\% of all respondents were male. Due to the fact that this research is focused on small and medium sized companies in Croatia, it is presumed that business owners and managers are familiar with the internal processes of decisionmaking, and therefore have given correct and accurate information.

From Figure 1, it can be concluded that business owners and managers have a significant impact on financial decision during all four functions of management: planning (48\%), organizing (43\%), leading (50\%) and controlling $(40 \%)$. But, if on the 5-point Likert scale manager's observation always and often present together, it can be concluded that the greatest impact on the financial decision process lies in the organizing $(82 \%)$ function. 
Management, Vol. 22, 2017, 1, pp. 103-116

M. Klačmer Čalopa: Business owner and manager's attitudes towards financial decision ...

\begin{tabular}{|c|c|c|c|c|c|}
\hline & Never & Rarely & $\begin{array}{c}\text { Periodicall } \\
y\end{array}$ & Often & Always \\
\hline - Planning & $3 \%$ & $7 \%$ & $13 \%$ & $30 \%$ & $48 \%$ \\
\hline - Organizing & $3 \%$ & $6 \%$ & $10 \%$ & $39 \%$ & $43 \%$ \\
\hline Leading & $5 \%$ & $8 \%$ & $15 \%$ & $23 \%$ & $50 \%$ \\
\hline C Controlling & $6 \%$ & $5 \%$ & $14 \%$ & $35 \%$ & $40 \%$ \\
\hline
\end{tabular}

Figure 1. Impact on financial decision-making from the aspects of four functions of management

Source: Research results.

This fact is not surprising since the most important choice of particular activities and actions that need to be undertaken for business success are performed in this function. The differences presented with some measures of descriptive statistic in Table 1 are almost negligible.

Table 1. Measures characterising answers to the survey question - Impact on financial decision-making from the aspects of four functions of management

\begin{tabular}{|l|c|c|c|c|c|c|}
\hline & Mean & $\begin{array}{c}\text { Standard } \\
\text { Error }\end{array}$ & Median & Mode & $\begin{array}{c}\text { Standard } \\
\text { Deviation }\end{array}$ & $\begin{array}{c}\text { Sample } \\
\text { Variance }\end{array}$ \\
\hline Planning & 4.123809524 & 0.1036824 & 4 & 5 & 1.062428623 & 1.128754579 \\
\hline Organizing & 4.133333333 & 0.0976525 & 4 & 5 & 1.00064082 & 1.001282051 \\
\hline Leading & 4.047619048 & 0.1151372 & 4 & 5 & 1.179805659 & 1.391941392 \\
\hline Controlling & 3.99047619 & 0.1095238 & 4 & 5 & 1.122285084 & 1.25952381 \\
\hline
\end{tabular}

Source: Research results.

From Figure 2, it can be concluded that, in the process of making financial decisions, managers and business owners use most frequent ethical principles (34\%), although a significant percentage of managers (owners) expressed the opinion that ethical principles are rarely represented $(33 \%)$ in their organization. 
Management, Vol. 22, 2017, 1, pp. 103-116

M. Klačmer Čalopa: Business owner and manager's attitudes towards financial decision ...

In addition to the ethical principles, the impact of higher-level management in the financial decision-making process is important (33\%).

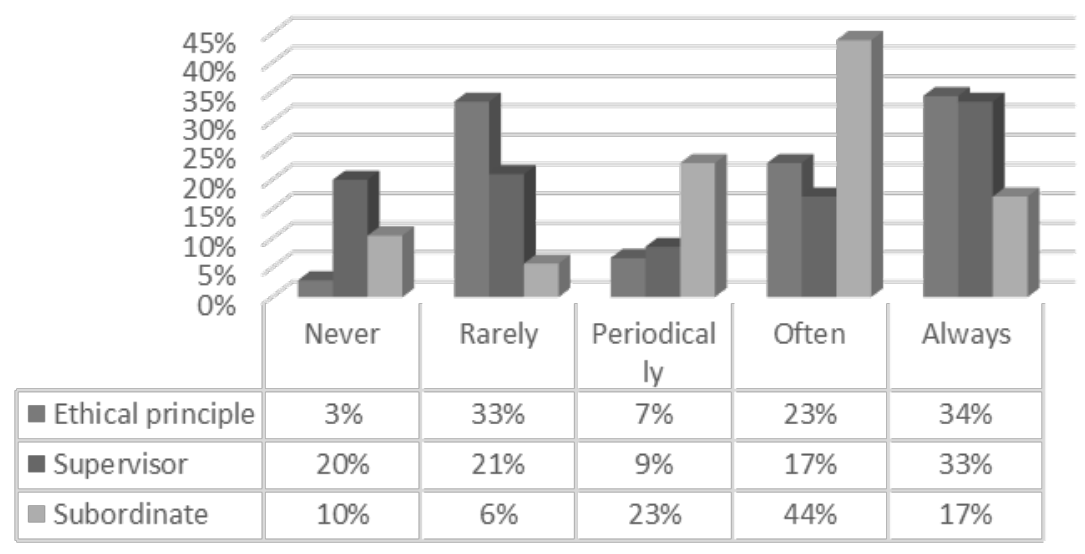

Figure 2. The impact of selected factors on the process of making financial decisions

Source: Research results.

It is also important to emphasize that $44 \%$ of managers stated that financial decisions are often the responsibility of lower-level management in their organizations, suggesting that they apply democratic decision-making style. This is not surprising if we know that strategic plans, which include financial plans and strategy, might not succeed if the strategy is misinterpreted or if lower-level managers resists its implementation. The differences presented with descriptive statistic in Table 3 show domination of two factors, ethical principles and supervision of higher-level of management in the process of financial decision-making.

Figure 3 shows a very strong, positive impact of financial decision-making process on the selected factors like innovation, intellectual capital, speed of decision-making and reward for the effort. It is important to notice that today's strategic financial decisions are made in a changing dynamic environment, so innovation, particularly in the field of finance are important (gsb.stanford.edu). Intellectual capital, as an intangible asset has an important role for organizations which want to be efficient on the market and to obtain sustainable competitive advantage (Gogan et al., 2016). 
Management, Vol. 22, 2017, 1, pp. 103-116

M. Klačmer Čalopa: Business owner and manager's attitudes towards financial decision ...

Table 3. Measures characterising answers to the survey question - The impact of selected factors on the process of making financial decisions

\begin{tabular}{|c|c|c|c|c|c|c|}
\hline & Mean & $\begin{array}{c}\text { Standard } \\
\text { Error }\end{array}$ & Median & Mode & $\begin{array}{c}\text { Standard } \\
\text { Deviation }\end{array}$ & $\begin{array}{c}\text { Sample } \\
\text { Variance }\end{array}$ \\
\hline $\begin{array}{c}\text { Ethical } \\
\text { principle }\end{array}$ & 3.885714 & 0.101557726 & 4 & 4 & 1.04065702 & 1.082967033 \\
\hline Supervisory & 3.266667 & 0.138189938 & 4 & 4 & 1.416025496 & 2.005128205 \\
\hline Subordinate & 2.847619 & 0.099247122 & 3 & 3 & 1.016980376 & 1.034249084 \\
\hline
\end{tabular}

Source: Research results.

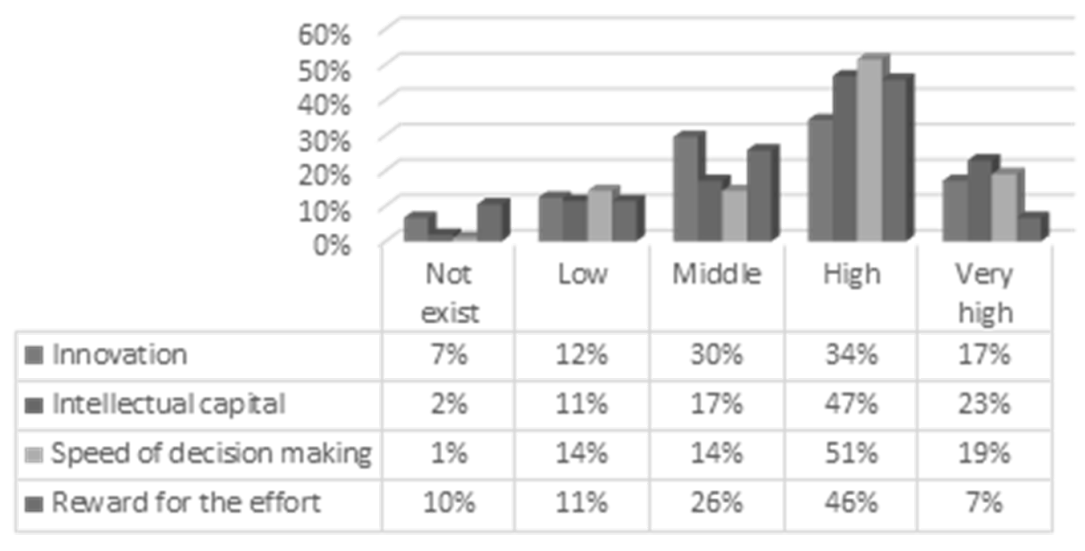

Figure 3. Level of positive impact of financial decision-making on the selected factors in the company

Source: Research results.

For the two highest levels of agreement on the Likert scale being aggregated, the most significant impact of financial decision-making is on the factors 'intellectual capital' and 'the speed of decision-making'. This is not surprising, since these two factors have a very important impact on the quality of decisions. 
Management, Vol. 22, 2017, 1, pp. 103-116

M. Klačmer Čalopa: Business owner and manager's attitudes towards financial decision ...

Table 4. Level of positive impact of financial decision-making to the selected factors in the company

\begin{tabular}{|l|c|c|c|c|c|c|}
\hline & Mean & $\begin{array}{c}\text { Standard } \\
\text { Error }\end{array}$ & Median & Mode & $\begin{array}{c}\text { Standard } \\
\text { Deviation }\end{array}$ & $\begin{array}{c}\text { Sample } \\
\text { Variance }\end{array}$ \\
\hline Innovation & 3.428571 & 0.108989 & 4 & 4 & 1.1168047 & 1.247253 \\
\hline Intellectual capital & 3.780952 & 0.097572 & 4 & 4 & 0.9998168 & 0.999634 \\
\hline $\begin{array}{l}\text { Speed of decision- } \\
\text { making }\end{array}$ & 3.733333 & 0.094022 & 4 & 4 & 0.963434 & 0.928205 \\
\hline Reward for effort & 3.266667 & 0.10679 & 4 & 4 & 1.0942741 & 1.197436 \\
\hline
\end{tabular}

Source: Research results.

\section{CONCLUSION AND RECOMMENDATIONS}

Literature used for this study has been analyzed with the purpose of presenting findings in the areas of business owners' and manager's attitudes towards their financial decision-making and strategic planning. Based on the literature review, analysis and discussion in the empirical part of the paper, the following can be concluded:

- The most influential role of business owners and managers in the process of financial decision-making is in the organizing function of management;

- Ethical principles and supervision of higher level management in the process of financial decision-making are dominant factors;

- Differences have been noted in the impact of financial decision-making process on the several selected factors but the most significant impact is on the intellectual capital and the speed of decision-making. Therefore, conducted research, presented and interpreted results can contribute to a better understanding of the strategic and financial decision-making roles and offer possibilities for further research on this and similar topics.

These results, however, should be interpreted with caution, because response rates, however comparable with other similar research, are rather small, and similar studies in other countries could produce different results. Furthermore, a limitation of this study is the use of a Likert scale as an opinionbased survey instrument. This type of survey measurement lacks a clear interval scale and is, therefore, ordinal in nature. The results of the survey are timebound and cannot be generalized to past or future. As for future research, it is suggested to include large companies into the future studies, as well as compare 
Management, Vol. 22, 2017, 1, pp. 103-116

M. Klačmer Čalopa: Business owner and manager's attitudes towards financial decision ...

the results with other studies of SMEs in other countries in Europe. It is also worth analyzing the financial literacy of business owners and managers and their impact on the financial decision process.

\section{REFERENCES}

1. Barr, K., Bell, J. (2011). An Executive Director's Guide to Financial Leadership, The Nonprofit quarterly, www.npqmag.org, Fall/Winter

2. Carpenter, M., Bauer, T., Erdogan, B. (2012). Management principles, http://2012books.lardbucket.org/books/management-principles-v1.1/s0504-planning-organizing-leading-an.html (Accessed: June, 2016)

3. Culkin, N., Smith, D. (2000). An Emotional Business: A Guide to Understanding the Motivations of Small Business Decision Takers, Qualitative Market Research: An International Journal, 3 (3), pp. 145-157.

4. Dmitrović, V. (2015), Intelektualni kapital kao strateška performansa organizacije, Doctoral dissertation, Fakultet organizacionih nauka, Univerzitet u Beogradu, http:/uvidok.rcub.bg.ac.rs/bitstream/ handle/123456789/402/Doktorat.pdf?sequence=1 (Accessed: November 2015)

5. Gogan, L. M., Artene, A., Sarca, I., Draghici, A. (2016). The Impact of Intellectual Capital on Organizational Performance, 13th International Symposium in Management: Management During and After the Economic Crisis, Procedia - Social and Behavioral Sciences, 221 (7), pp. 194-202.

6. Grebe, M. (2005). Strategic financial planning: What every trustee needs to know about facility replacement, Trustee, 58 (10), pp. 24-28.

7. İbicioğlu, H., Kocabiyik, T., Dağlar, H. (2010). Financial statement utilization during decision-making process in SMEs: a comparative study on European and Turkish managers, Marmara University Journal of the Faculty of Economic \& Administration, 28 (1), http://dosya. marmara.edu.tr/ikf/iib-dergi/2010-1/12-ibicioglu-kocabiyik-dalgar.pdf (Accessed: November 2015)

8. Jones, R. (2002). Fundamentals of Strategic and Tactical Business Planning, 2002 MAST Program, http://www.agmanager.info/farmmgt/ planning/Busplanintro.pdf (Accessed: November 2015)

9. Jouzani, J. J. (2015). The relationship between intellectual capital and organizational intelligence: Case study of Sepah Bank, Golestan Province, Iran, http://pharmascope.org/ijrls/index.php/announce/download/846 (Accessed: November 2015)

10. Karadag, H. (2015). Financial Management Challenges In Small and Medium-Sized Enterprises: A Strategic Management Approach, Emerging 
Markets Journal, 5 (1), https://emaj.pitt.edu/ojs/index.php/emaj/article/ view/67 (Accessed: March 2017)

11. Klapper, L., Lusardi, A., Panos, G. A. (2015). Financial Literacy and Entrepreneurship, Global Financial Literacy, http://gflec.org/wpcontent/uploads/2015/05/WP-2015-3-Financial-Literacy-andEntrepreneurship.pdf (Accessed: March 2017)

12. Kono, P. M.; Barnes, B. (2010). The Role of Finance in the StrategicPlanning and Decision-Making Process, Graziadio Business Review, 13 (1), https://gbr.pepperdine.edu/2010/08/the-role-of-finance-in-the-strategicplanning-and-decision-making-process/

13. Kraus, S., Reiche, S., Reschke, H. (2007). Implications of strategic planning in SMSs for international entrepreneurship research and practice, Energizing Management through Innovation and Entrepreneurship: European Research and Practice, pp. 110-127. London: Routledge

14. Kraus, S., Reiche, S., Reschke, H. (2007). The role of strategic planning in SMEs: literature review and implications, Conference proceedings of the Annual Meeting of the British Academy of Management, Oxford, UK

15. Liu, Z. (2010). Strategic Financial Management in Small and MediumSized Enterprises, International Journal of Business and Management, 5 (2), pp. 132-136.

16. Niles, N. (2010), A Case Study In Strategic Financial Planning In Health Service Organizations, Journal of Business Case Studies, 6 (5), pp. 27-30.

17. Njuguna Chege, A., Wachira, A., Mwenda, L. (2015). Effects of Leadership Styles on Implementation of Organization Strategic Plans in Small and Medium Enterprises in Nairobi, Management and Administrative Sciences Review, 4 (3), pp. 593-600.

18. Pasadilla, G. (2010). Financial Crisis, Trade Finance and SMEs: Case of Central Asia (Working paper), Asian Development Bank Institute, https://www.adb.org/sites/default/files/publication/156042/adbi-wp187.pdf (Accessed: November 2015)

19. Posner, B. G. (1985). Real entrepreneurs don't plan, Inc. 7 (11): 129-32.

20. Reboud, S., Mazzarol, T. (2008), Strategic planning in SMEs, a Review of the English and French Literature, Paper presented at ANZAM Annual Conference, 25 December, Auckland (NZ).

21. Sage, S. (2015), Strategic Implementation, http://onstrategyhq.com/ resources/strategic-implementation/ (Accessed: November 2015)

22. Shahzad, I., Ullah, S., Azam, K., Khan Marwat, A. (2010). Global Financial Crisis and its Effects on Entrepreneurship, http://www. wbiconpro.com/4\%5B1\%5D.\%20Irfan.pdf (Accessed: November 2015)

23. Sprenger, J. (2016). Financial Literacy - A Barrier to Seek Financial Advice but not a Shield Against Following it, Ruhr Economic Papers, 
http://www.rwi-essen.de/media/content/pages/publikationen/ruhreconomic-papers/rep_16_634.pdf (Accessed, 2017)

24. Van Auken, H., Yang K. (2014). Chinese SMEs' uses of financial statements in decision-making, Journal of Developmental Entrepreneurship, 19 (4), https://doi.org/10.1142/S1084946714500277

25. Verreynne, M. T. (2006). Strategy making process and firm performance in small firms, Journal of Management and Organization, 12 (3), pp. 209222.

26. Vidučić, Lj. et al. (2013), SME's business environment: The case of Croatia, International Journal of Economic Sciences, 2 (3), pp. 152-165.

27. Winbladh, J. (2013). Ethical Issues Facing the Financial Service Industry, Vysoka Skola Manazmentu, Bratislava (SK), http://www.cutn.sk/Library/ proceedings/mch_2013/editovane_prispevky/8.Winbladh.pdf (Accessed: June, 2016)

28. http://smallbusiness.chron.com/relationship-between-strategic-financialplanning-21063.html (Accessed: June, 2016)

29. http://www.gsb.stanford.edu/exed/ecfo/ (Accessed: June, 2016)

30. http://blink.ucsd.edu/finance/accountability/ethics/process.html (Accessed: June, 2016)

31. http://study.com/academy/lesson/organizing-as-a-function-ofmanagement.html (Accessed: June, 2016)

32. CIMA (2007). Improving decisions making in organization: the opportunity to transform finance

33. Singer, S., Šarlija, N., Pfeifer, S., Oberman Peterka, S. (2016). Što čini Hrvatsku (ne)poduzetničkom zemljom? http://www.cepor.hr/wpcontent/uploads/2017/05/GEM2016-FINAL-za-web.pdf (Accessed: March, 2017)

\title{
PODUZETNIČKI I MENADŽERSKI STAVOVI PREMA FINANCIJSKOM ODLUČIVANJU I STRATEŠKOM PLANIRANJU: DOKAZI IZ MALIH I SREDNJIH HRVATSKIH PODUZEĆA
}

\begin{abstract}
Sažetak
Temeljni cilj ovog rada je istražiti stavove poduzetnika i menadžera malih i srednjih poduzeća (MSP) u Hrvatskoj prema financijskom odlučivanju i strateškom planiranju. Nadalje se pokušavaju utvrditi stilovi menadžmenta i poduzetničke vještine, kao i razina znanja o financijama. Podaci su prikupljeni korištenjem on-line upitnika i analizirani korištenjem standardnih alata deskriptivne statistike. Istraživački se uzorak sastoji od 106 ispitanika iz hrvatskih MSP (što daje stopu odgovora od 14\%). Rezultati istraživanja ukazuju da poduzetnici i menadžeri MSP skrbe za financijske rezultate, ali,
\end{abstract}


Management, Vol. 22, 2017, 1, pp. 103-116

M. Klačmer Čalopa: Business owner and manager's attitudes towards financial decision ...

na žalost, ne utječu na financijsko odlučivanje u svim njegovim fazama. Ovaj bi rad mogao doprinijeti boljem razumijevanju poduzetnika i menadžera hrvatskih MSP prema financijskom odlučivanju i strateškom planiranju.

Ključne riječi: mala i srednja poduzeća, poduzetnici, menadžeri, financijsko odlučivanje, strateško planiranje 